\title{
Using ecosystem approach indicators for assessing the ecological status of reef fisheries management in a marine protected area
}

\author{
ERNIK YULIANA ${ }^{1,2, \vartheta}$, MENNOFATRIA BOER ${ }^{2}$, ACHMAD FAHRUDIN ${ }^{2}$, MOHAMMAD MUKHLIS KAMAL ${ }^{2}$, \\ SHINTA TRILESTARI PARDEDE \\ ${ }^{1}$ Faculty of Mathematics and Natural Sciences, Universitas Terbuka. Jl. Cabe Raya Pondok Cabe, Pamulang, Tangerang Selatan, Banten, Indonesia \\ Tel./Fax. +62-21-7490941, `email: ernik@ecampus.ut.ac.id \\ ${ }^{2}$ Program of Coastal and Marine Resources Management, Postgraduate Program, Institut Pertanian Bogor. Dramaga, Bogor 16890, West Java, Indonesia \\ ${ }^{3}$ Wildlife Conservation Society Indonesia Marine Program, Bogor, West Java, Indonesia
}

Manuscript received: 4 May 2019. Revision accepted: 3 June 2019.

\begin{abstract}
Yuliana E, Boer M, Fahrudin A, Kamal MM, Pardede ST. 2019. Using ecosystem approach indicators for assessing the ecological status of reef fisheries management in a marine protected area. Biodiversitas 20: 1802-1810. The purpose of this study was to assess the status of reef fisheries management in a marine protected area base on ecosystem approach indicators and to determine the tactical decisions required to improve management. The study site was in Karimunjawa National Park (KNP) Jepara, Central Java, Indonesia. Data were collected using survey and observation methods and included both primary and secondary data. Coral fish, which were the object of the study was Caesio cuning, Caesio caerulaurea, Plectropomus oligacanthus, and Parupeneus barberinus. Determination of the status of each ecosystem approach indicator was conducted using the flag model. Tactical decisions were necessary to improve the status of management indicators. The results indicated that the ecological status of reef fisheries management of KNP is at a moderate level with an achievement value of $62.75 \%$ Tactical decisions are necessary to push the ten indicators to achieve a better level. Three indicators still received a poor status, and the remaining (seven indicators) were within the moderate status. Therefore, the three indicators that need to be improved quickly are fish abundance, fishing gear modification, and fishing capacity.
\end{abstract}

Keywords: Ecosystem approach, Karimunjawa, reef fisheries, marine protected area

\section{INTRODUCTION}

The world's marine capture fisheries production had increased from 90.2 million tons in 2009 to 93.4 million tons in 2014. Most of the ten main capture fish species stocks have been fully exploited (FAO 2016). To avoid overexploitation, there needs to be fisheries management that ensures the sustainability of both fish resources and the ecosystem (Pomeroy et al. 2010; FAO 2011), because the current management of fisheries is unable to avoid the symptoms of overfishing and habitat damage (Cristie et al. 2007).

Fisheries management is all efforts, including integrated processes in information collection, analysis, planning, consultations, decision making, resource allocation, and the implementation and law reinforcement of regulations in the field of fisheries, conducted by the government or any other authority which are directed towards the achievement of marine biological resource productivity and other purposes which have been determined (Indonesian Law No. 45/2009; Garcia et al. 2005). In the beginning, fisheries management was mainly focused on fish resources as a single species, but then developed with the inclusion of the social aspect (Caddy 1999; Garcia et al. 2005), and focused on marine ecosystems (Pomeroy et al. 2010).

In 2001, FAO introduced the ecosystem approach to fisheries (EAF) as an improvement to the previous fisheries management approaches (Adrianto et al. 2016). EAF is an effort to balance the socio-economic purpose (fishers welfare and fish resources utilization equality) with consideration of science, information, and uncertainties of the biotic, abiotic, and human interaction components in aquatic ecosystems through an integrated, comprehensive, and sustainable fisheries management (Garcia et al. 2005).

The application of the EAF concept in fisheries management is hence known as the ecosystem approach to fisheries management (EAFM). EAFM focuses on fisheries management to make decisions related to the multi-use on other ecosystem components (Pomeroy et al. 2010). EAFM was adopted by the Ministry of Marine Affairs and Fisheries (MMAF) Indonesia, implemented in creating fisheries management plans for a certain fisheries management area or a prioritized fish species. MMAF, through a national task force, has formulated a set of reference indicators for the implementation of EAFM (Adrianto et al. 2016). EAFM requires complacency to similar principles, transparent and participative management, which has guided many current management practices. Better collaboration and coordination between fisheries institutions and non-fishery institutions are needed (Garcia et al. 2005; Monintja 2013).

Karimunjawa National Park (KNP) is a marine protected area (MPA) in Indonesia that has high coral reef and fish resource biodiversity (Campbell et al. 2013; KNPA 2014). The main purpose of declaring an MPA is to protect, preserve, and utilize natural resources as a 
sustainable way to increase fish production, support the provision of food and nutrition, and increase fishers' income (Nainggolan et al. 2013; Bennet and Dearden 2014; White 2014). The benefits of an MPA for local fishers are improving fisheries productivity and fish biodiversity, protecting the habitat, and regulating the utilization of coastal and marine resources (Ulloa et al. 2013). In KNP, there are fishing activities which are mainly conducted by local fishers (Campbell and Pardede 2006). MPA and fisheries management have been implemented by the Karimunjawa National Park authority (KNPA) by practicing the zoning system. However, destructive fishing practices and violations of the zonation are still conducted by fishers even though they have been prohibited by KNPA (Campbell et al. 2013; KNPA 2013; Yuliana et al. 2016a). As a result, the coral cover declined from 2012 to 2013 in the protection zone (from $62.24 \pm 9.73$ to $55.65 \pm 11.74$ ) and the tourism zone (from $60.89 \pm 9.96$ to $58.51 \pm 16.79$ ), and there was also and a peak of the reef fish catch decline in 2009 at 200,875 kg (Muttaqin et al. 2013).

In order to make the management of reef fisheries in KNP more effective, there needs to be a novel approach to achieving sustainable fisheries: the EAFM. This approach is expected to reduce conflict between conservation purposes and fisheries activities (Rees et al. 2013), especially reducing the impact of MPA on the fisher's economic welfare (Weigel et al. 2015). MPA is often perceived as severely limiting fishers' activities in catching fish, especially in using the fishing gear. Therefore, there need to be EAFM indicators that are attuned to the needs of MPA management, because fisheries management within an MPA has a stricter precautionary approach than that of outside an MPA (FAO 2011; Adrianto et al. 2016). The use of EAFM indicators to assess the effectivity of MPA has been conducted by Pregiwati et al. (2015) at the Anambas Islands, but the development of the indicators and criteria for MPA have never been conducted before.

Implementation of EAFM requires assessment indicators to evaluate the status of the ecosystem (Bellido et al. 2011). EAFM implementation indicators in Indonesia were developed in six domains: (i) fish resources, (ii) habitat, (iii) fish-catching technology, (iv) social, (v) economy and (vi) institution; which were assessed based on the study areas (Adrianto et al. 2016; MMAF 2014). EAFM is a strategy, not a ready-to-implement method; thus it needs several criteria that could be used to assess the ecosystem as a whole, the status of human impact, and environmental variation (Allain et al. 2012). In this study, the status evaluation is limited to the ecological status, which consists of the domains of fish resources, habitat, and fish-catching technology. Each EAFM indicator must fulfill the conditions: measurable and could be understood by the stakeholders; based on ease of obtaining data and data reliability; the ability to reflect the condition of the resources; related to the benchmark values and management measures (Ye et al. 2011).

The overall objective of this work is to assess the ecological status of reef fisheries management in KNP using the ecosystem approach to fisheries assessment
(EAFA) approach and to determine tactical decisions in future management in order to achieve better results.

\section{MATERIALS AND METHODS}

\section{Study area}

This study was conducted in KNP in Jepara District, Central Java Province, Indonesia (Figure 1).

\section{Methodology \\ Object of study}

The object of the study was the waters of Karimunjawa National Park, included fish, habitat, community, and governance. The EAFM domains used in this study referred to the domains used by MMAF (MMAF 2014) with modifications to the indicators and criteria to align with precautionary approaches in an MPA.

\section{Data collection}

Data collection was conducted using the survey and observation methods, utilizing both primary and secondary data. The EAFM domains used in this study referred to the domains used by MMAF (MMAF 2014) with modifications to the indicators and criteria to align with precautionary approaches in an MPA. The number of indicators resulting from the modifications in this study was 18 (Table 1).

The fish resources domain used primary data collected from four types of reef fish (based on the biomass and price), were the redbelly yellowtail fusilier (Caesio cuning), blue and gold fusilier (Caesio caerulaurea), highfin coral grouper (Plectropomus oligacanthus) and dash-and-dot goatfish (Parupeneus barberinus). The fish length data were collected by sampling six times (every two weeks for three months, from 15 April - 15 July 2015). The fish samples were taken from 4 wholesalers in Karimunjawa Village. Primary data that were collected included fish length, amounts of catch, fishing trips, and the prices of fish. Secondary data for the period 2010-2014 were obtained from the Wildlife Conservation Society (WCS) Indonesia Marine Program, in the form of fish catches and fishing trips.

The habitat domain used primary data in the form of water turbidity and coral cover. The coral recruitment indicator used secondary data, and identification of unique habitats was conducted through interviews with several informants. The fishing technology domain used primary data in the form of the number of trips and the types of fishing gear, and the rest used secondary data from KNPA and WCS.

\section{Data analysis}

The determination of the status of each EAFM indicator was done using a flag model (MMAF 2014). The reference point value used was 3 (good), the one below it was 2 (moderate), and the lowest 1 (poor). The analysis of fish resource domains for each fish species was conducted by adopting the method used by Zhang et al. (2009). The analysis was conducted by calculating the species score, 
followed by calculating the subdomain score. The species score $(\mathrm{SpS})$ was defined as:

$$
S p S_{i}=\frac{\sum I S_{i} \times I W_{i}}{\sum I W_{i}}
$$

where " $\mathrm{SpS}_{\mathrm{i}}$ " is the score of species, "IS $\mathrm{S}_{\mathrm{i}}$ " is the status score for indicator " $\mathrm{i}$ " (Table 1), "IW $\mathrm{i}_{\mathrm{i}}$ " is the weighting factor for the indicator ' $i$ ”. And, subdomain score (SdS) was defined as:

$$
S d S_{i}=\frac{\sum S p S_{i}}{\sum S p}
$$

where "SdS $\mathrm{i}_{\mathrm{i}}$ " is the score of subdomain " $\mathrm{i}$ ", "Sp" is the species. The domain composite score was calculated using the formula:

$$
D C S=\sum I S_{i} \times I W_{i} \times D S_{i}
$$

where "DCS" is the domain composite score, "DS $\mathrm{i}$ " is the density score of the indicator "i", whereas the indicator score was calculated by the formula:

$$
I S_{i}=\frac{\sum I S_{S p i}}{\sum S p}
$$

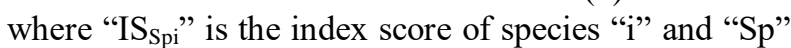
is the species.

Inter-indicator connectivity (density value) was assessed with logical causal analysis (LCA). Identification was made by determining the density score $\left(\mathrm{sd}_{i}\right)$ from the results of the inter-indicator connectivity cognitive mapping. The maximum density would be $n-1$ ( $n$ is the number of total EAFM indicators assessed). The indicator with the highest (most) connectivity plays a large role in the ecosystem of an area.

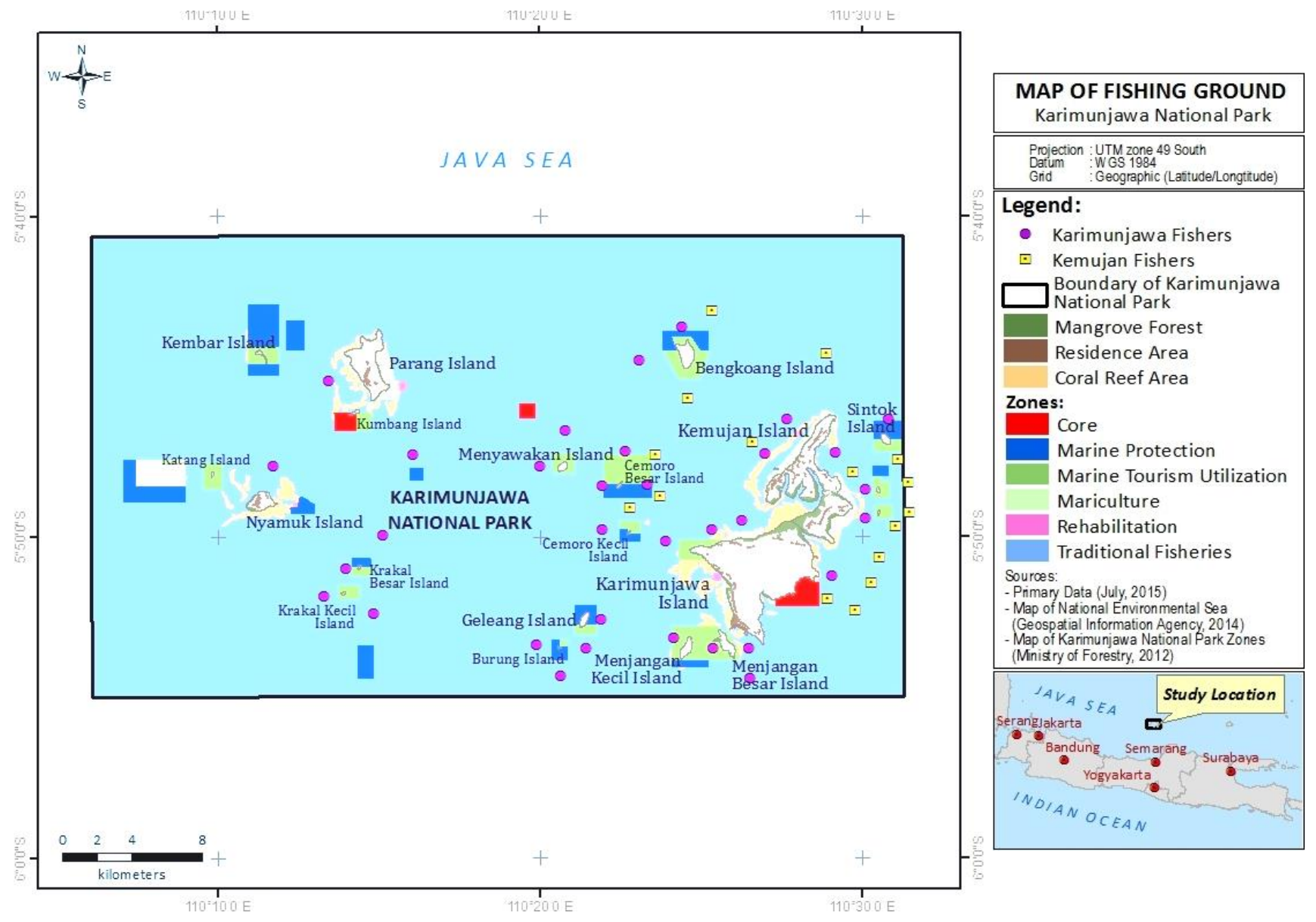

Figure 1. The study site at Karimunjawa National Park, Central Java, Indonesia 
Table 1. Data collection method and data requirements for each EAFM domain

\begin{tabular}{|c|c|c|c|}
\hline Domain & Indicator & Criteria & Type of Data \\
\hline \multirow[t]{13}{*}{ Fish resources } & Sustainability Subdomain & & \\
\hline & 1. CPUE & $1=$ sharp decline $; 2=$ gradual decline $; 3=$ incline & $\begin{array}{l}\text { Secondary } \\
\text { (WCS 2014) }\end{array}$ \\
\hline & 2. Change in fish length mode & $1=$ sharp decline $; 2=$ stable $; 3=$ incline & Primary \\
\hline & 3. Exploitation rate $(\mathrm{E})$ & $1=$ value of $E>0.5 ; 2=$ value of $E=0.5 ; 3=$ value of $E<0.5$ & Primary \\
\hline & 4. Proportional of juvenile & $\begin{array}{l}1=\text { proportion }>60 \% ; 2=\text { proportion } 30-60 \% \\
3=\text { proportion }<30 \%\end{array}$ & $\begin{array}{l}\text { Secondary } \\
\text { (WCS 2014) }\end{array}$ \\
\hline & Diversity Subdomain & & \\
\hline & 5. Fish abundance & 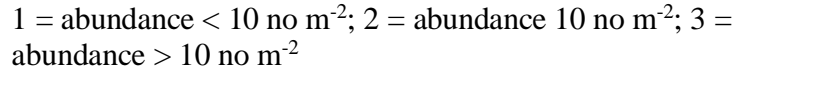 & $\begin{array}{l}\text { Primary and } \\
\text { secondary } \\
\text { (WCS 2014) }\end{array}$ \\
\hline & 6. Fish biomass & $\begin{array}{l}1=\text { biomass }<500 \mathrm{~kg} \mathrm{ha}^{-1} ; 2=\text { biomass } 500-1000 \mathrm{~kg} \mathrm{ha}^{-1} ; 3= \\
\text { biomass }>1000 \mathrm{~kg} \mathrm{ha}^{-1}\end{array}$ & $\begin{array}{l}\text { Secondary } \\
\text { (WCS 2014) }\end{array}$ \\
\hline & 7. Species frequency & $1=$ decline $; 2=$ stable $; 3=$ incline & $\begin{array}{l}\text { Primary and } \\
\text { secondary }\end{array}$ \\
\hline & Conservation Subdomain & & \\
\hline & 8. Number of species & $\begin{array}{l}1=\text { number of species }<50 \text { species } ; 2=\text { number of species } 51- \\
100 \text { species } ; 3=\text { number of species }>100 \text { species }\end{array}$ & $\begin{array}{l}\text { Secondary } \\
\text { (WCS 2014) }\end{array}$ \\
\hline & 9. Change in family composition & $1=\mathrm{a}$ lot of change $; 2=\mathrm{a}$ little change $; 3=$ no change & $\begin{array}{l}\text { Secondary } \\
\text { (WCS 2014) }\end{array}$ \\
\hline & 10. ETP* species & $\begin{array}{l}1=\text { many catches of ETP species; } 2=\text { little catches of ETP } \\
\text { species; } 3=\text { no catches of ETP species }\end{array}$ & Primary \\
\hline \multirow[t]{4}{*}{ Habitat } & 11. Water turbidity & $\begin{array}{l}1=\text { turbidity }>5 \mathrm{mg} \mathrm{L}^{-1} ; 2=\text { turbidity } 5 \mathrm{mg} \mathrm{L}^{-1} ; 3=\text { turbidity }< \\
5 \mathrm{mg} \mathrm{L}^{-1}\end{array}$ & Primary \\
\hline & 12. Coral cover & $\begin{array}{l}1=\text { coral cover } 0-25 \% ; 2=\text { coral cover } 26-50 \% ; 3=\text { coral } \\
\text { cover } 51-75 \% \text { and } 76-100 \%\end{array}$ & $\begin{array}{l}\text { Primary and } \\
\text { secondary } \\
\text { (WCS 2014) }\end{array}$ \\
\hline & 13. Coral recruitment & $1=$ decline $; 2=$ stable $; 3=$ incline & Primary \\
\hline & 14. Unique habitats & $\begin{array}{l}1=\text { none } ; 2=\text { present, but not well managed } ; 3=\text { present and } \\
\text { well managed }\end{array}$ & $\begin{array}{l}\text { Secondary } \\
\text { (WCS 2014) }\end{array}$ \\
\hline \multirow[t]{4}{*}{$\begin{array}{l}\text { Fishing } \\
\text { technology }\end{array}$} & 15. Destructive fishing & $\begin{array}{l}1=\text { number of violations }>10 \text { cases year }{ }^{-1} ; 2=\text { number of } \\
\text { violations } 5-10 \text { cases year }^{-1} ; 3=\text { number of violations }<10 \\
\text { cases year }{ }^{-1}\end{array}$ & $\begin{array}{l}\text { Secondary } \\
\text { (WCS 2014) }\end{array}$ \\
\hline & $\begin{array}{l}\text { 16. Modification of fishing gear } \\
\text { and supporting equipment }\end{array}$ & $\begin{array}{l}1=\text { use of supporting equipment }<30 \% \text { trip; } 2=\text { use of } \\
\text { supporting equipment } 31-50 \% ; 3=\text { use of supporting } \\
\text { equipment }>50 \%\end{array}$ & Primary \\
\hline & 17. Fishing capacity ratio & $1=$ value of $\mathrm{R}<1 ; 2=$ value of $\mathrm{R}=1 ; 3=$ value of $\mathrm{R}>1$ & $\begin{array}{l}\text { Secondary } \\
\text { (WCS 2014) }\end{array}$ \\
\hline & 18. Fishing selectivity & $\begin{array}{l}1=\text { unselective use of fishing gear }>75 \% \\
2=\text { unselective use of fishing gear } 50-75 \% ; 3=\text { unselective use } \\
\text { of fishing gear }<50 \%\end{array}$ & Primary \\
\hline
\end{tabular}

Note: ${ }^{*} \mathrm{CPUE}=$ catch per unit effort; $\mathrm{ETP}=$ endangered, threatened, protected

Table 2. The classification of domain index values

\begin{tabular}{|c|c|c|}
\hline $\begin{array}{l}\text { Composite } \\
\text { value }\end{array}$ & aggregate & Description \\
\hline $100-3567$ & & Poor \\
\hline $3568-7035$ & & Moderate \\
\hline $7036-10500$ & & Good \\
\hline
\end{tabular}

Table 3. The limits for domain and aggregate composite scores (MMAF 2014)

\begin{tabular}{ccl}
\hline \multicolumn{2}{l}{ Range of value } & Description \\
\cline { 1 - 2 } Low & High & \\
\hline 1.00 & 33.00 & Poor in implementing EAFM \\
34.00 & 67.00 & Medium in implementing EAFM \\
78.00 & 100.00 & Good in implementing EAFM \\
\hline
\end{tabular}

The composite value of the ecological status was defined as:

$$
E S=\frac{\sum D C S_{i}}{\sum D}
$$

where "ES" is the ecological status, "DCS $\mathrm{P}_{\mathrm{i}}$ " is the domain composite score, and " $D$ " is the domain. The criteria for the value of domain index (Table 2) was determined by considering the value of density (Table 2), and limitations of the domain composite score divided by three groups (Table 3).

Tactical decisions were applied to the indicators that had values less than the reference point or those with scores of 1 and 2 . These tactical decisions were necessary for the 
authorities to increase the score or fishery condition from the poor category to the moderate category or from score 1 to score 2, and from the moderate category to the good category or from score 2 to score 3 (Gavaris 2009).

\section{RESULTS AND DISCUSSION}

\section{Fish resources domain}

Fish resources are one of the domains in EAFM, which focuses on the biological aspect of fish. The total number of indicators in the fish domain resources was 10. All of those indicators were classified into three subdomains: sustainability, diversity, and conservation. In sustainability subdomain, the reef fish resources at KNP has a high diversity. The analysis of the four target reef fish species (Table 4) included the catch per unit effort (CPUE) indicator, change in fish length mode, exploitation rate, and proportion of juveniles (the determination of the proportion of juveniles in Table 5). The diversity subdomain is focused on the condition of fish resources in the waters. Assessment of the diversity subdomain status (Table 6) used the following indicators: fish abundance, fish biomass, and fish species frequency. Assessment of the conservation subdomain status (Table 7) used the following indicators: the number of species, changes in the family composition, and endangered, threatened, protected (ETP) species.

Table 4. The results of the species score determination and sustainability subdomain score

\begin{tabular}{|c|c|c|c|c|}
\hline \multirow{2}{*}{ Indicators } & \multicolumn{4}{|c|}{ Indicator's score of fish species } \\
\hline & Caesio cuning & Caesio caerulaurea & $\begin{array}{l}\text { Plectropomus } \\
\text { oligacanthus }\end{array}$ & $\begin{array}{c}\text { Parupeneus } \\
\text { barberinus }\end{array}$ \\
\hline CPUE & 2 & 2 & 2 & 2 \\
\hline (Weight: 40) & (gradual decline) & (gradual decline) & (gradual decline) & (gradual decline) \\
\hline ChPange in fish length mode & 1 & 2 & 1 & 3 \\
\hline (Weight: 25) & (decline) & (stable) & (decline) & (incline) \\
\hline Exploitation rate $(\mathrm{E})$ & 3 & 1 & 1 & 3 \\
\hline (Weight: 25) & $(\mathrm{E}=0.41)$ & $(\mathrm{E}=0.57)$ & $(\mathrm{E}=0.77)$ & $(E=0.26)$ \\
\hline Proportion of fish $<\mathrm{Lm}$ size & 3 & 2 & 1 & 3 \\
\hline (Weight: 10) & $(15.67 \%)$ & $(36.20 \%)$ & $(62.30 \%)$ & $(16.04 \%)$ \\
\hline Species score & 2.10 & 1.75 & 1.40 & 2.60 \\
\hline Subdomain score & 1.96 & & & \\
\hline
\end{tabular}

Table 5. The analysis and results of the determination of the proportion of fish $<\mathrm{L}_{\mathrm{m}}$ size

\begin{tabular}{|c|c|c|c|c|c|}
\hline Species of fish & $\begin{array}{l}\mathbf{L}_{\mathbf{m}} \\
(\mathbf{c m})\end{array}$ & $\begin{array}{l}\text { Number of } \\
\text { samples } \\
\text { (individuals) }\end{array}$ & $\begin{array}{l}\text { Number of } \\
\text { fish }<\mathrm{L}_{m} \\
\text { (individuals) }\end{array}$ & $\begin{array}{c}\text { The } \\
\text { proportion of } \\
\text { juveniles }(\%)\end{array}$ & The basis of $L_{m}$ determination \\
\hline Caesio cuning & 19.6 & 2,515 & 394 & 15.67 & $\begin{array}{l}\text { Male's Lm } 18.95 \text { cm; female's } L_{m} 20.25 \\
\text { cm (Triyono et al. 2011) }\end{array}$ \\
\hline C. caerulaurea & 21.2 & 837 & 304 & 36.20 & $\mathrm{~L}_{\mathrm{m}} 21.2 \mathrm{~cm}$ (fish base.org) \\
\hline Plectropomus oligacanthus & 41.5 & 687 & 428 & 62.30 & $\begin{array}{l}\mathrm{L}_{\mathrm{m}} 41.5 \mathrm{~cm} \text { (fish base.org) } \\
\text { Gonad-mature highfin coral grouper 1590- } \\
1650 \mathrm{~g}, \pm 40 \mathrm{~cm} \text { (Sembiring et al. (2014) }\end{array}$ \\
\hline Parupeneus barberinus & 25.0 & 106 & 17 & 16.04 & $\begin{array}{l}\text { Maximum length } 40 \mathrm{~cm} \text { (KNPA 2012); } \\
\text { Maximum length } 60 \mathrm{~cm} \text { (fish base.org) }\end{array}$ \\
\hline
\end{tabular}

Table 6. The analysis results of the species score determination and diversity subdomain

\begin{tabular}{|c|c|c|c|c|}
\hline \multirow[t]{2}{*}{ Indicators } & \multicolumn{4}{|c|}{ Fish species } \\
\hline & Caesio cuning & Caesio caerulaurea & Plectropomus oligacanthus & Parupeneus barberinus \\
\hline Fish abundance & $\begin{array}{l}3 \\
\left(88,12 \mathrm{nom}^{-2}\right.\end{array}$ & 2 & 1 & 1 \\
\hline $\begin{array}{l}\text { (Weight: 40) } \\
\text { Fish biomass }\end{array}$ & $\begin{array}{l}\left(88.12 \mathrm{no} \mathrm{m}^{-2}\right) \\
3\end{array}$ & $\begin{array}{l}\left(10.28 \mathrm{no} \mathrm{m}^{-2}\right) \\
3\end{array}$ & $\begin{array}{l}\left(0.09 \text { no }^{-2}\right) \\
1\end{array}$ & $\begin{array}{l}\left(0.35 \text { no }^{-2}\right) \\
1\end{array}$ \\
\hline (Weight: 30) & $\left(13.27 \mathrm{~kg} \mathrm{ha}^{-1}\right)$ & $\left(1.93 \mathrm{~kg} \mathrm{ha}^{-1}\right)$ & $\left(0.05 \mathrm{~kg} \mathrm{ha}^{-1}\right)$ & $\left(0.08 \mathrm{~kg} \mathrm{ha}^{-1}\right)$ \\
\hline Species frequency & 2 & 2 & 1 & 3 \\
\hline (Weight: 30) & (Stable) & (Stable) & (Decline) & (Incline) \\
\hline Species score & 2.70 & 2.30 & 1.00 & 1.60 \\
\hline Subdomain score & 1.90 & & & \\
\hline
\end{tabular}


Table 7. The results of the species score and conservation subdomain scores

\begin{tabular}{ccccc}
\hline Year & Number of species score (40) & $\begin{array}{c}\text { Family composition } \\
\text { change score (40) }\end{array}$ & ETP species score (20) & $\begin{array}{c}\text { Subdomain } \\
\text { score }\end{array}$ \\
\hline $2010-2013$ & $\begin{array}{c}3 \\
\text { (number of species }>100 \text { species) }\end{array}$ & (no change) & (little catches of ETP species) \\
\hline
\end{tabular}

Table 8. Analysis of fish resources domain

\begin{tabular}{lllllll}
\hline Subdomain & Indicator & Score & Weight (\%) & Density & Value & Total \\
\hline Sustainability & CPUE & 2.00 & 13.3 & 29 & 771.40 & $4,493.29$ \\
& Change in fish length mode & 1.75 & 8.3 & 27 & 332.18 \\
& Exploitation rate & 2.00 & 8.3 & 27 & 448.20 \\
Diversity & Proportion of juvenile & 2.25 & 3.4 & 28 & 214.20 \\
& Fish abundance & 1.00 & 13.3 & 32 & 0.42 \\
& Fish biomass & 1.75 & 10.0 & 29 & 507.50 \\
Conservation & Species frequency & 2.00 & 10.0 & 21 & 120.00 \\
& Number of species & 3.00 & 13.3 & 23 & 317.70 \\
& Change in family composition & 3.00 & 6.8 & 23 & 317.70 \\
Maximum value & ETP species & 2.00 & 6.8 & 15 & 204.00 & 10,200 \\
Composite value & & & & & & $44.05 \%$ \\
\hline
\end{tabular}

Table 9. Analysis of the habitat domain score

\begin{tabular}{|c|c|c|c|c|c|c|}
\hline Indicators & Result & Score & Weight (\%) & Density & Value & Total \\
\hline Water turbidity & $1.54 \mathrm{mg} \mathrm{L}^{-1}$ & 3 & 20 & 27 & 1,620 & 8,710 \\
\hline Coral cover & $53.94 \%$ & 3 & 40 & 33 & 3,960 & \\
\hline Coral recruitment & Increased at the period $2009-2013$ & 3 & 30 & 33 & 2,970 & \\
\hline Uniques habitats & Non existent & 1 & 10 & 16 & 160 & \\
\hline Maximum value & & & & & & 10,200 \\
\hline Composite value & & & & & & $85.39 \%$ \\
\hline
\end{tabular}

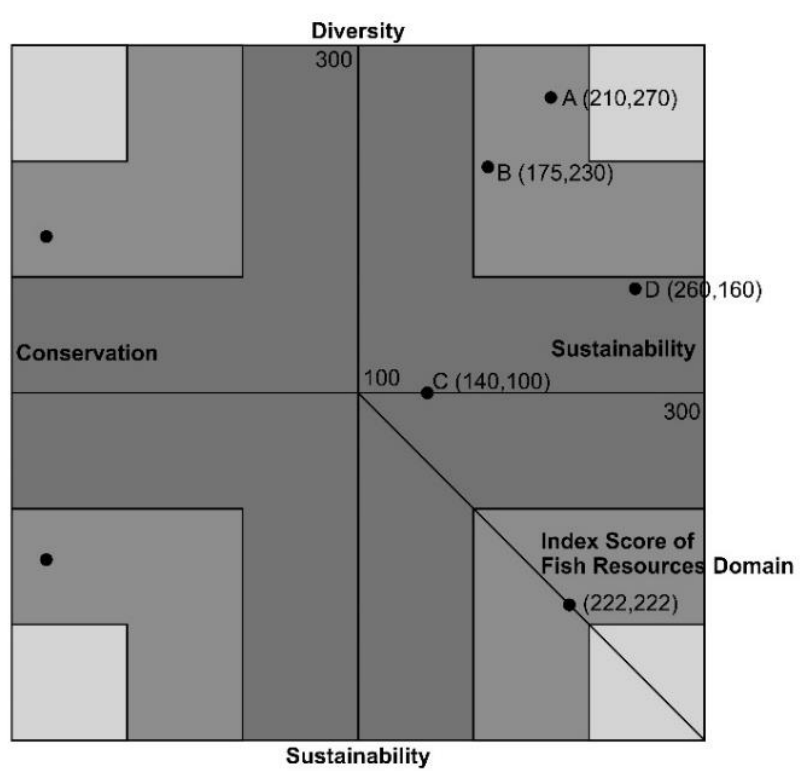

Figure 2. Calculation of fish resources inter-subdomain connectivity. $\mathrm{A}=$ Caesio cuning; $\mathrm{B}=C$. caerulaurea; $\mathrm{C}=$ Plectropomus oligacanthus $; \mathrm{D}=$ Parupeneus barberinus
The analysis of fish resources domain scores showed that the fish resource domain had a composite value of 4,493.92, within the moderate level, with a domain composite value of $44.05 \%$, which was also within the moderate level (Table 8). The position of each species and subdomain in the fish resources domain (Figure 2) showed that red belly yellowtail fusilier fish (Caesio cuning) and blue-and-gold fusilier (Caesio caerulaurea) were in the moderate area in the sustainability and diversity subdomain. Highfin grouper fish (Plectropomus oligacanthus) and dash-and-dot goatfish (Parupeneus barberinus) were in the poor area, which means that the two fish had poor sustainability and diversity. From the four fish used as the object of the observations, none were in the good area. The diversity and conservation subdomain connectivity was in the moderate area, and so was the connectivity between conservation and sustainability subdomains. Judging from the results of the analysis of the three subdomains, there need to be efforts to push the three subdomains to the good area.

\section{Habitat domain}

Results of the habitat domain score analysis demonstrated that the habitat domain had a score of 8,710 , within a good level, with a composite value of $82.95 \%$ (Table 9). This means that the condition of the habitat in 
KNP was well-preserved, even though there were some threats of organic pollution and destructive fishing. Nevertheless, the habitat's good condition did not automatically have a good impact on fish resources.

\section{Fishing technology domain.}

Results of the fishing technology domain score analysis showed that the domain had a score of 6210 , in the moderate level, with a composite value of $58.82 \%$ (Table
10). The fishing technology condition strongly influences fish resources (Campbell and Pardede 2006).

In aggregate, the ecological status in KNP was moderate, with a composite value of $62.75 \%$ (Table 11). The habitat domain had the highest composite value $(85.39 \%)$, and the lowest domain composite was fish resources $(44.05 \%)$. In order to improve the ecological status in managing fisheries in KNP, tactical steps need to be taken to encourage management to reach a better status (Table 12).

Table 10. Analysis of the fish catching technology domain

\begin{tabular}{|c|c|c|c|c|c|c|}
\hline Fish catching technology indicators & Result & Score & $\begin{array}{c}\text { Weight } \\
(\%)\end{array}$ & Density & Value & Total \\
\hline Destructive fishing & 1.25 cases in average annually & 3 & 30 & 33 & 2,970 & 6,000 \\
\hline $\begin{array}{l}\text { Modification of fishing gear and } \\
\text { supporting equipment }\end{array}$ & $\begin{array}{l}67 \% \text { of trips use compressor } \\
\text { spearguns }\end{array}$ & 1 & 30 & 25 & 750 & \\
\hline Fishing capacity ratio $(\mathrm{R})$ & 0.95 & 1 & 20 & 30 & 600 & \\
\hline Fishing selectivity & Selective fishing gear & 3 & 20 & 28 & 1680 & \\
\hline Maximum value & & & & & & 10,200 \\
\hline Composite value & & & & & & $58.82 \%$ \\
\hline
\end{tabular}

Table 12. Tactical decision management reef fishery in KNP

\begin{tabular}{|c|c|c|c|c|c|}
\hline \multirow{2}{*}{$\begin{array}{l}\text { Domain } \\
\text { andIndicator }\end{array}$} & \multicolumn{2}{|c|}{ Actual value } & \multicolumn{2}{|c|}{ Reference Indicator } & \multirow[t]{2}{*}{ Tactical decision } \\
\hline & Score & Criteria & Score & Criteria & \\
\hline \multicolumn{6}{|l|}{ Fish resources } \\
\hline CPUE & 2.00 & $\begin{array}{l}\text { Slight } \\
\text { decrease }\end{array}$ & 3.00 & $\begin{array}{l}\text { Stable or } \\
\text { increased }\end{array}$ & Regulate the maximum catching effort \\
\hline $\begin{array}{l}\text { Change in fish length } \\
\text { mode }\end{array}$ & 1.75 & $\begin{array}{l}\text { Tended to be } \\
\text { stable }\end{array}$ & 3.00 & Increased & $\begin{array}{l}\text { Educate the fishers in the subsequent three years } \\
\text { about the } \mathrm{L}_{\mathrm{m}} \text { size of fish species and encourage } \\
\text { them to catch fish above the } \mathrm{L}_{\mathrm{m}} \text { size }\end{array}$ \\
\hline Exploitation rate & 2.00 & $\begin{array}{l}\text { Moderate } \\
(\mathrm{E}=0.5)\end{array}$ & 3.00 & $\begin{array}{l}\text { Sustainable } \\
(E<0.5)\end{array}$ & $\begin{array}{l}\text { Regulate fishing gear used by the fishers such as } \\
\text { banning the use of compressors. }\end{array}$ \\
\hline Proportion of juvenile & 2.25 & $30-60 \%$ & 3.00 & $<30 \%$ & $\begin{array}{l}\text { Encourage the fishers to catch fish above the } \\
\text { Lmsize so that the proportion of premature fish < } \\
30 \%\end{array}$ \\
\hline Fish abundance & 1.00 & $\begin{array}{l}\text { Low } \\
\left(2.95 \text { no }^{-2}\right)\end{array}$ & 3.00 & $\begin{array}{l}\text { Moderate } \\
\left(10{\left.\text { no } \mathrm{m}^{-2}\right)}^{-2}\right.\end{array}$ & $\begin{array}{l}\text { Increase the percentage of coral cover as fish } \\
\text { habitat to very good by supporting the village } \\
\text { agreement to avoid destructive fishing }\end{array}$ \\
\hline Fish biomass & 1.75 & $\begin{array}{l}\text { Moderate } \\
\left(10 \mathrm{~kg} \mathrm{ha}^{-1}\right)\end{array}$ & 3.00 & $\begin{array}{l}\text { High } \\
(>10 \mathrm{~kg} \\
\left.\mathrm{ha}^{-1}\right)\end{array}$ & $\begin{array}{l}\text { Increase surveillance of pollution and } \\
\text { destructive fishing through the increased } \\
\text { integrated patrol }\end{array}$ \\
\hline Species frequency & 2.00 & $\begin{array}{l}\text { Slightly } \\
\text { decreased }\end{array}$ & 3.00 & Increased & $\begin{array}{l}\text { Maintain the aquatic habitat health in all the } \\
\text { waters by increasing surveillance on domestic } \\
\text { waste }\end{array}$ \\
\hline ETP species & 2.00 & $\begin{array}{lr}\text { A few ETP } \\
\text { species are } \\
\text { found at } \\
\text { wholesalers }\end{array}$ & 3.00 & $\begin{array}{l}\text { No ETP species } \\
\text { at wholesalers }\end{array}$ & $\begin{array}{l}\text { Educate fishers about ETP species and building } \\
\text { the wholesalers' awareness of not purchasing } \\
\text { ETP species. }\end{array}$ \\
\hline \multicolumn{6}{|l|}{ Fishing techniques } \\
\hline $\begin{array}{l}\text { Modification } \\
\text { fishing gears }\end{array}$ & 1.00 & $\begin{array}{l}\text { Use of } \\
\text { compressors is } \\
67 \%\end{array}$ & 2.00 & $\begin{array}{l}\text { Use of } \\
\text { compressors } \\
\text { decrease }\end{array}$ & $\begin{array}{l}\text { Educate fishers of the dangers of using a } \\
\text { compressor and ban the use of compressors as a } \\
\text { fishing tool as soon as possible. }\end{array}$ \\
\hline Fishing capacity & 1.00 & Ratio $<1$ & 2.00 & Ratio $=1$ & $\begin{array}{l}\text { Regulate catching efforts so that the catching } \\
\text { capacity increases. }\end{array}$ \\
\hline
\end{tabular}


Table 11. Composite value of the ecological status in KNP

\begin{tabular}{lll}
\hline Domain & Composite value & Description \\
\hline Fish resources & 44.05 & Moderate \\
Habitat & 85.39 & Good \\
Fish-catching technique & 58.82 & Moderate \\
Aggregate & 62.75 & Moderate \\
\hline
\end{tabular}

\section{Discussion}

The analysis of fish resources domain demonstrated that the domain needed attention because KNP is an MPA which is expected to protect its biodiversity and ecosystem (FAO 2011; Indonesian Law 45/2009), so that it may supply fish stock for the waters outside the MPA (FAO 2011; White 2014). It is hoped that the fish resources in the KNP area could be protected and sustainably utilized.

One of the critical indicators in fisheries resources domain is the exploitation rate. The fish exploitation rate is obtained from the analysis of mortality based on the size of fish caught (Sparre and Venema 1998). The analysis of exploitation rate was based on the criteria in Pauly (1987), that the rational and sustainable exploitation rate $(\mathrm{E})$ for a certain body of waters $\mathrm{E}<0.5$ or maximum $\mathrm{E}=0.5$. The redbelly yellowtail fusilier fish (Caesio cuning) had an exploitation rate (E) of 0.41 ; blue-and-gold fusilier (Caesio caerulaurea) 0.57; highfin grouper (Plectropomus oligacanthus) 0.77; and dash-and-dot goatfish (Parupeneus barberinus) 0.26 [31]. From the four species of fish, there were two fish that were exploited more than is sustainable, the blue-and-gold fusilier and highfin grouper. These results were in accordance with the findings of Yulianto et al. (2015) who found that the highfin grouper's CPUE has declined drastically in the period 2009-2011 to only 0.06$0.15 \mathrm{~kg}$ trip $^{-1}$ with fishing rods.

Therefore, there need to be efforts to control the exploitation rate of this fish; one of the efforts is through fishing gear regulation (Campbell and Pardede 2006). At the moment, blue-and-gold fusiliers and highfin groupers are usually caught using spearguns with the help of compressors. If compressors are banned, this could help decrease the exploitation rate (Yuliana et al. 2016b).

From the habitat point of view, in the aggregate, there has been an increase in coral cover by $2.92 \%$, from $72.00 \%$ in 2010 to $74.55 \%$ in 2013. In 2015, the average coral cover was $53.94 \%$ (Yuliana 2016), which was in the good category (Gomez et al. 1988). One of the factors that had caused the increase in coral cover in the period 2010-2013 was the decline in potassium cyanide use and the ban on the muro-ami fish-catching gear since 2012 (Campbell et al. 2013). The physical factors that influence coral reef growth also strongly affect the community structure and life form of the coral reef (Aldyza et al. 2015). The maximum depth of the Karimunjawa waters is $50 \mathrm{~m}$ (Campbell and Pardede 2006), and coral reef lives in the waters surrounding the island and at depths of less than 50 $\mathrm{m}$.

Coral cover in KNP is related to the conditions of the waters, especially the turbidity. The water turbidity in KNP was $1.54 \mathrm{mg} \mathrm{L}^{-1}$ (Yuliana 2016), categorized as suitable for the life of marine biota (Decree of the Minister of
Environment 51/2004). One of the factors that contribute to water turbidity is the effect of pollution from domestic waste and tourism facility construction (Campbell et al. 2013). Controlling water turbidity is an important factor because coral reefs are very sensitive to water turbidity. The control can be done by explaining to the local community about the effect of domestic activities on marine waters.

The fishing technology condition strongly influences fish resources. Campbell and Pardede (2006) explained that the selectivity of fishing gear strongly influenced coral fish abundance and biomass. Therefore, there need to be regulations for fishing gear so that only mature fish are caught.

Based on the assessment of the ecological status in $\mathrm{KNP}$, it was in the moderate category $(62.75 \%)$ in aggregate. The status depends on the fisheries activities and the management (Charles 2001). The status needs to be improved so that it could be in a good category. One of the efforts is by formulating and implementing tactical management decisions in order to improve the current performance (Gavaris 2009).

Implementation of EAFM requires policy planning, strategic planning, and operational management planning (Garcia et al. 2005). Policy planning is needed in the macro context, which focuses on statements of commitment from both national and regional decision makers. In policy planning, there also needs to be included the fundamental and terminal objective statements of the implementation of EAFM through the combination of socio-economic and environmental consideration and fish resource purposes. In policy planning, the mechanisms for central and regional coordination, inter-sectoral coordination, and the relationship between national and international regulations need to be included. Strategic planning focuses more on strategy formulation to achieve the purposes stated in the policy plan (MMAF 2014).

Managerial decisions in EAFM implementation consist of both strategic and tactical decisions (Gavaris 2009). Strategies are made based on what is necessary to fulfill managerial purposes. Strategic decisions must be able to facilitate the comparison of domain values resulting from the alternative reference chosen. Tactical decisions are made for the technical implementation of managerial strategies in the field, which drive EAFM implementation towards a better status. Determination of the tactical decisions is basically for improving an indicator status that has not yet reached the reference point (Adrianto et al. 2016).

\section{ACKNOWLEDGMENTS}

The first author is grateful to the Ministry of Research, Technology and Higher Education for funding the research through the doctoral dissertation research scheme, The Karimunjawa National Park Authority for granting permission to conduct research in KNP, and WCS Indonesia Marine Program for providing secondary data. 


\section{REFERENCES}

Adrianto L, Ruchimat T, Habibi A. 2016. Building integrated reference indicators and knowledge management system for the implementation of EAFM in Indonesia. National Working Group Ecosystem Approach to Fisheries Management, Ministry of Marine Affairs and Fisheries, Republic of Indonesia. [Indonesian].

Aldyza N, Sarong MA, Rizal S. 2015. Monitoring of hard coral covers and zonation of marine conservation area of Tuan Island, Aceh Besar District, Indonesia. AACL Bioflux 8 (5): 640-647.

Allain V, Nicol S, Polovina J, Coll M, Olson R, Griffiths S, Dambacher J, Young J, Molina JJ, Hoyle S, Lawson T. 2012. Internationa workshop on opportunities for ecosystem approaches to fisheries management in the Pacific Ocean tuna fisheries. Reviews in Fish Biology Fisheries 22: 29-33.

Bellido JM, Santos MB, Pennino MB, Valeiras X, Pierce GC. 2011. Fishery discards and bycatch: solutions for an ecosystem approach to fisheries management? Hydrobiologia 670: 317-333.

Bennett NJ, Dearden P. 2014. Why local people do not support conservation: Community perceptions of marine protected area livelihood impacts, governance, and management in Thailand. Marine Policy 44: 107-116.

Caddy JF. 1999. Fisheries management in twenty-first century: will new paradigms apply? Reviews in Fish Biology and Fisheries 9: 1-43.

Campbell SJ, Kartawijaya T, Yulianto I, Prasetia R, Clifton J. 2013. Comanagement approaches and incentives improve management effectiveness in the Karimunjawa National Park, Indonesia. Marine Policy 41: 72-79.

Campbell SJ, Pardede ST. 2006. Reef fish structure and cascading effects in response to artisanal fishing pressure. Fisheries Research 79: 7583.

Charles AT. 2001. Sustainable fishery systems. Blackwell Sciences, London.

Cristie DL, Fluharty AT, White L, Eisma-Osorio W, Jatulan. 2007. Assessing the feasibility of ecosystem-based fisheries management in tropical contexts. Marine Policy 31: 239-250.

Decree of the Minister of Environment No. 51/2004 on Sea Water Quality Standard for Marine Life. [Indonesian].

FAO (Food and Agricultural Organization). 2016. The State of world fisheries and aquaculture. FAO, Rome.

FAO (Food and Agricultural Organization). 2011. Fisheries management: Marine protected areas and fisheries. FAO, Rome.

Fish Base. http://www.fishbase.org (assessed 26.10.16).

Garcia SM, Cochrane KL. 2005. Ecosystem approach to fisheries: a Review of implementation guidelines. ICES Journal of Marine Sciences 62: 311-318.

Gavaris S. 2009. Fisheries management planning and support for strategic and tactical decisions in an ecosystem approach context. Fisheries Research 100: 6-14.

Gomez ED, Yap HT. 1988. Monitoring reef condition. In: Kenchington RA, Hudson BET (eds) Coral Reef Management Handbook. UNESCO regional office for science and technology for Southeast Asia (ROSTSEA), Jakarta.

Indonesian Law No. 45/2009 on Fisheries. [Indonesian].

KNPA (Karimunjawa National Park Authority). 2014. Karimunjawa National Park Authority statistics 2013. BTNKJ, Semarang. [Indonesian].

KNPA (Karimunjawa National Park Authority). 2013. Report on the implementation of security problem data analysis in KNP. BTNKJ, Semarang. [Indonesian].

KNPA (Karimunjawa National Park Authority). 2012. Identification guide of reef fish species. BTNKJ, Semarang. [Indonesian].

MMAF (Ministry of Marine Affairs and Fisheries). 2014. Assessment of indicators of ecosystem approach to fisheries management. Direktorat Sumber Daya Ikan, Kementerian Kelautan dan Perikanan, Jakarta. [Indonesian].

Monintja D. 2013. The ecosystem approach to reef fisheries management (EAFM)]. In: Nikijuluw V, Adrianto L, Januarini N (eds) Coral Governance. IPB Press, Bogor. [Indonesian].
Muttaqin E, Pardede ST, Tarigan SAR, Sadewa S. 2013. The 2013 technical report on the Karimunjawa park coral reef ecosystem monitoring (Monitoring phase 6). Wildlife Conservation Society Indonesia Program, Bogor. [Indonesian].

Nainggolan P, Susanto HA, Megawanto R. 2013. The marine protected area approach to reef ecosystem management. In: Nikijuluw $\mathrm{V}$, Adrianto L, Januarini N (eds) Coral Governance. IPB Press, Bogor. [Indonesian].

Pauly D. 1987. Review of the ELEFAN system for analysis of lengthfrequency data in fish and aquatic invertebrates, in: Length-Based Methods in Fisheries Research. ICLARM Conference Proceedings 13, International Center for Living Aquatic Resources Management, Manila, Philippines, and Kuwait. Institute for Scientific Research, Safat, Kuwait.

Pomeroy R, Garces L, Pido M, Silvestre G. 2010. Ecosystem-based fisheries management in small-scale tropical marine fisheries: Emerging models governance arrangements in the Philippines. Marine Policy 34: 298-308.

Pregiwati LA, Wiryawan B, Baskoro MS, Wisudo SH, Satria A. 2015. Linking indicators for ecosystem approach to fisheries management and management of marine protected area effectiveness in Anambas Island, Indonesia. AACL Bioflux 8 (6): 1048-1061.

Rees SE, Rodwell LD, Searle S, Bell A. 2013. Identifying the issues and options for managing the social impacts of Marine Protected Areas on a small fishing community. Fisheries Research 146: 51-58.

Sparre P, Venema SC. 1988. Introduction to Tropical Fish Stock Assessment Part I: Manual. FAO Fisheries Technical Paper, Rome.

Sembiring SBM, Andamari R, Muzaki A, Wardana IK, Hutapea JH, Astuti NWW. 2014. Gonadal development of Plectropomus leopardus which is reared in floating net cages. Jurnal Ilmu dan Teknologi Kelautan Tropis 6 (1):53-61. [Indonesian].

Triyono H, Goenawati I, Siswanti NS. 2011. The biological and fishing aspect of Caesio cuning which is landed in the Karimunjawa fishing port, Jepara Regency, Central Java Province. Sekolah Tinggi Perikanan, Jakarta. [Indonesian].

Ulloa R, Vargas A, Hudson C, Rivadeneira MM. 2013. Zoning of the Mejillones Peninsula marine protected coastal area of multiple uses, northern Chile. Latin American Journal of Aquatic Research 41 (3): 506-518.

WCS (Wildlife Conservation Society). 2014. Karimunjawa fish landing and ecological data. [unpublished].

Weigel JY, Morand P, Mawongwai T, Noel JF, Tokrishna R. 2015. Assessing economic effects of marine protected area on fishing household. A Thai case study, Fisheries Research 161: 64-76.

White A. 2014. Building capacity for effective participation in a regional wide system of MPAs (CTMPAS) in the coral triangle. IUCN World Parks Congress 14 November 2014.

Ye Y, Cochrane K, Qiu Y. 2011. Using ecological indicators in the context of an ecosystem approach to fisheries for data-limited fisheries. Fisheries Research 112: 108-116.

Yuliana E, Fahrudin A, Boer M, Kamal MM, Pardede ST. 2016a. The effectiveness of the zoning system in the management of reef fisheries in the marine protected area of Karimunjawa National Park, Indonesia. AACL Bioflux 9 (3): 483-497.

Yuliana E, Boer M, Fahrudin A, Kamal MM, Muttaqin E. 2016b. Stock status of target reef fishes in marine protected area of Karimunjawa National Park. Jurnal Penelitian Perikanan Indonesia 22 (1):9-16. [Indonesian].

Yuliana E. 2016. Management of Coral Reef Fisheries through Ecosystem Approach to Fisheries (EAF) in Marine Protected Area (Case: Karimunjawa National Park. [Dissertation], Institut Pertanian Bogor, Bogor. [Indonesian].

Yulianto I, Hammer C, Wiryawan B, Palm HW. 2015. Fishing-induced groupers stock dynamics in Karimunjawa National Park, Indonesia. Fisheries Science 81: 417-432.

Zhang CI, Kim S, Gunderson D, Marasco R, Lee JB, Park HW, Lee JH. 2009. An ecosystem-based fisheries assessment approach for Korean fisheries. Fisheries Research 100: 26-41. 